\title{
Microbiological, Physico-Chemical and Sensorial Characteristics of Serrano, an Artisanal Brazilian Cheese
}

\author{
Ana Paula Longaray Delamare*, Cristiane Conte Paim de Andrade, Fernanda Mandelli, \\ Renata Chequeller de Almeida, Sergio Echeverrigaray
}

Institute of Biotechnology, University of Caxias do Sul, Rio Grande do Sul, Brazil.

Email: *aplongar@yahoo.com

Received May 21 ${ }^{\text {st }}$, 2012; revised June 21 ${ }^{\text {st }}, 2012$; accepted June $28^{\text {th }}, 2012$

\begin{abstract}
The microbiological, chemical and sensory characteristics of licensed and unlicensed commercial Serrano cheese, a traditional product from the highlands of South Brazil, were studied. The average bacteria counts (log CFU/g) were 8.8, 3.4, 3.4, 5.1, and 8.8, for mesophilic bacteria, fecal coliforms, staphylococci, yeasts and moulds, and lactic acid bacteria (LAB), respectively. Differences in microbiological quality were detected between licensed and unlicensed cheeses. However, the presence of potential gastroentheric bacteria in both kind of cheeses is disturbing and point out the necessity of alternative manufacturing process and good manufacturing practices to minimize consumers' health risks. The most prevalent LAB were Lactobacillus (91\%), followed Lactococcus and Enterococcus. Lactobacillus isolates comprised L. plantarum (57.7\%), L. paracasei (19.2\%), L. rhamnosus (7.7\%), L. acidophilus (7.7\%), and 3.8\% of both $L$. curvatus and L. fermentum. Non-significant physico-chemical differences were detected between licensed and unlicensed cheeses. Cheeses that received the highest sensorial scores exhibited the presence of both $L$. plantarum and $L$. paracasei, indicating that mixed populations of these species positively contributed to flavor development.
\end{abstract}

Keywords: Serrano Cheese; Lactic Acid Bacteria; Microbiological Characterization; TAP-PCR

\section{Introduction}

Cheese is a dairy product produced and consumed all over the world, and plays an important role in human nutrition. It is estimated that more than a 1000 types of cheeses are produced around the world. Although the largest word production corresponds to industrial cheeses, most varieties can be classified as artisanal products. Although Brazil is not renowned as a cheese producer, the manufacture and consumption of industrial and artisanal cheese has experimented a huge increase in the last decades, reaching 675 thousand tons in 2011 [1].

Nowadays, Brazilian market experience a growing interest in traditional or artisanal products, including dairy products due to their uniqueness and a general concern of natural quality.

Serrano cheese, produced in the highlands (750 to 950 m) of South Brazil, is a farm-made product with high acceptance by the local consumers, and economically important for small farmers. The annual production of Serrano cheese is estimated in more than 800 tons, involving approximately 3.5 thousand farms (unofficial

"Corresponding author. data) distributed in the Northeast region of Rio Grande do Sul and the South of Santa Catarina States.

Serrano cheese can be described as an uncooked, semihard product with strong flavor, manufactured from cow raw milk and fermented by natural microbial populations. Its rind is thin, uniform and smooth, with a soft strawyellow color. Cheese bulk has whitish color with small irregularly distributed holes [2]. It is consumed after a short period of ripening, usually 15 to 30 days, although the present Brazilian regulation on food safety for cheeses made from raw milk states a minimum ripening period of 60 days prior to consumption [3].

The mayor problems of Serrano cheese are the absence of standardization, including shape, weight, moisture, salt content [4], and the microbiological quality of the commercialized product [2]. In an attempt to solve part of these problems, the Caxias do Sul County, the most important producer of Serrano cheese, has financed the construction of small farm factories following good manufacturing practice (GMP). The families that joined to this program are licensed by the Municipal Agricultural Control Service (COPAS), which confers the right to manufacture and commercialize artisanal products 
within the county. Licensing involves mechanized milking, the construction of a specific place for cheese production and ripening, and the use of stainless steel equipments.

In the present work, we investigated the microbiological, physico-chemical and sensory characteristics of traditional Serrano cheese produced by licensed and nonlicensed farmers and commercialized at Caxias do Sul, RS.

\section{Material and Methods}

\subsection{Cheese Samplimg}

Serrano cheeses were bought in supermarkets or agroindustrial markets at Caxias do Sul, Rio Grande do Sul, between August and September 2006. Each sample consisted of one whole cheese. A total of 20 cheeses manufactured in different dairies were sampled: ten licensed (1 to 10 ) and ten non licensed cheeses (11 to 20). Licensed products are inspected by the Municipal Service of Agricultural Control (COPAS), where the non licensed cheeses correspond to illegally commercialized products.

Cheeses were transported to the laboratory and analyzed on arrival. Sampling was performed according to International Dairy Federation (IDF) Standard 50B [5].

\subsection{Microbiological Analysis}

Microbiological analyses were performed according with the normative 62 of the "Ministerio de Agricultura, Pecuaria e Abastecimento" of Brazil [6]. Briefly, $25 \mathrm{~g}$ of cheese were homogenized with $225 \mathrm{~mL}$ of buffered $0.1 \%$ $(\mathrm{w} / \mathrm{v})$ peptone water, in a Stomacher Lab-Blender MK 1204 (ITR Ltd., Esteio, Brazil). Decimal dilutions were prepared in sterile $0.1 \%(\mathrm{w} / \mathrm{v})$ peptone water, and aliquots were plated in triplicate on different media.

The number of mesophylic bacteria was determined on Plate Count Agar (Oxoid, Basingstoke, England) incubated at $37^{\circ} \mathrm{C}$ for $48 \mathrm{~h}$. Moulds and yeasts were enumerated on potato dextrose agar plates after incubation at $30^{\circ} \mathrm{C}$ for 5 days. Total coliforms were determined by the most probable number (MPN) according with the Normative Instruction No. 62 [6]. Briefly, a presumptive analysis was done on Lauryl Sulphate Tryptose Broth (Vetec, Rio de Janeiro, Brazil). Total coliforms were confirmed on Brilliant Bile Green Broth 2\% (Merck, Darmastadt, Germany). Fecal coliforms were determined on violet red bile agar after incubation for $24 \mathrm{~h}$ at $44^{\circ} \mathrm{C}$. Coagulase positive staphylococci were determined by colony counting on Baird Parker Agar (Merck, Darmastadt, Germany), and confirmed by coagulase test using Coagu-plasma LB (Laborclin, Pinhais, Brazil). Salmonella were enriched on Rappaport Vasilliadis Broth and Selenite Cystine Broth, and plated on Rambach Agar, and Brilliant Green Phenol Red Lactose Sucrose Agar (Merck, Darmastadt, Germany).

Lactic acid bacteria were enumerated on MRS agar plates after incubation at $30^{\circ} \mathrm{C}$ for $72 \mathrm{~h}$ in an anaerobic jar (Oxoid, Basingstoke, England) with anaerobiose produced by Anaerocult A (Merk, Darmastadt, Germany). Colonies with different morphologies were individually counted, sampled, and purified. Lactic acid bacteria identification at the genus level was performed according with the following criteria: Gram staining, microscopic examination, catalase test, growth at $10^{\circ} \mathrm{C}$ and $45^{\circ} \mathrm{C}$ in MRS broth, salt tolerance $(6.5 \% \mathrm{NaCl})$, production of carbon dioxide from glucose, and growth on MRS at $\mathrm{pH}$ 9.6.

Presumptive mesophylic lactobacilli (gram-positive, catalase-negative, non-motile rods) were classified at the species level on the basis of sugar fermentation using the API 50 CHL system (bioMerieux, Marcy-l’Étoile, France) as recommended by De Angelis et al. [7]. The requirement of Tween 80 for growth [8] was also evaluated as an additional classification trait. Ten isolates were selected for 16S rRNA sequencing in order to confirm phenotypic classification. The universal primers $16 S F$ (5'-CCAGCAGCCGCGGTAATACG-3') and 16SR (5'TACGGYTACCTTGTTACGACTTC-3’) were used for PCR amplification and sequencing [9]. DNA sequencing reactions were performed using the DYEnamic ET Dye terminator sequencing (MEGABACE) kit and run on a MegaBACE 1000 capillary sequencer (Amersham Biosciences).

Thirty three lactobacilli that represent the most prevalent LAB isolated from twelve cheeses were submitted to molecular identification using triplicate arbitrary primedPCR (TAP-PCR). The genetic fingerprinting of each isolate was obtained by TAP-PCR according with the method described by Swearingen et al. [10]. The primer used was 5'-CAGCAGCCGCGGTAATWC-3', and amplifications were performed at three annealing temperatures $\left(38^{\circ} \mathrm{C}, 40^{\circ} \mathrm{C}\right.$ and $42^{\circ} \mathrm{C}$ ) in a Mastercycler Gradient thermocycler (Eppendorf, Hamburg, Germany). PCR products were separated on $2 \%$ agarose gels along with 100 bp DNA ladder, stained with ethidium bromide, and digitalized under UV light using a UVItec transilluminator (UVItec, Cambridge, UK).

\subsection{Physico-Chemical Analysis}

The physico-chemical characteristics of Serrano cheeses were evaluated according reliable methodologies. Moisture and ashes were measured as described by the methods 925.10 and 923.03 of the Official Methods of Analysis [11]. Total proteins, fats, acidity, and $\mathrm{NaCl}$ concentration were determined by the methodology recommended by the "Ministério da Agricultura, Pecuária e Abasteci- 
mento" of Brazil. All analyses were carried out in triplicate.

\subsection{Sensorial Analysis}

The sensorial quality of Serrano cheeses was evaluated by hedonic ratings and characteristics profile. The sensory panel was composed by 15 non-trained tasters familiarized with Serrano cheese. The analysis was performed in isolated cabins in the Sensorial Analysis Laboratory at the University of Caxias do Sul.

In hedonic rating, each taster received a whole sample $2 \mathrm{~cm}$ edge and was requested to taste, carefully, each one. The test evaluated the global acceptability of the samples using a nine point's structured scale. The results were used to calculate the acceptability index. To obtain this index, it was considered the higher mean grade equal 1 and the index corresponds to percentage equivalent to mean. The sample that obtained an index higher than 0.7 was considered accepted.

In characteristics profile test, the tasters evaluated the attributes: appearance, color, odor, taste and texture, by conferring a grade $(1=$ bad, $3=$ good and $5=$ excellent $)$. The means of each attribute were analyzed by direct comparison.

\subsection{Statistical Analysis}

Plate counts were transformed to logarithms before statistical treatment. Statistical analyses were performed using the SSPS 10.0 program. Statistical significances were determined by the ANOVA analysis and differences between means were compared using the Tukey's test at the $5 \%$ level of significance.

TAP-PCR analysis was performed visually from the digitalized gels. Only bands present in the three annealing temperatures were considered. The presence (1) or absence (0) of bands was used to create a matrix and to calculate Jaccard's distances between bacterial isolates. Cluster analysis was carried out by the unweighted pair group method with arithmetic average (UPGMA) using SPSS and MEGA 4.0 programs.

\section{Results}

\subsection{Microbiological Analysis}

The number of mesophilic bacteria in Serrano cheeses varied between 7.91 and $9.47 \log \mathrm{CFU} / \mathrm{g}$. As can be observed in Table 1, no differences in mesophilic bacteria counting were observed between licensed and unlicensed commercial Serrano cheeses.

Table 1. Microbial populations (log CFU/g) in commercial Serrano cheese.

\begin{tabular}{|c|c|c|c|c|c|c|c|c|}
\hline & Samples & $\begin{array}{c}\text { Mesophilic } \\
\text { Bacteria }\end{array}$ & $\begin{array}{c}\text { Total } \\
\text { coliforms }\end{array}$ & $\begin{array}{c}\text { Fecal } \\
\text { coliforms }\end{array}$ & S. aureus & $\begin{array}{l}\text { Yeasts \& } \\
\text { moulds }\end{array}$ & $\begin{array}{c}\text { LAB } \\
\text { M17 media }\end{array}$ & $\begin{array}{c}\mathrm{LAB} \\
\text { rogosa media }\end{array}$ \\
\hline \multirow{10}{*}{$\begin{array}{c}\text { Licensed } \\
\text { Serrano cheese }\end{array}$} & 1 & 8.72 & $>3.50$ & 2.84 & 1.12 & 5.00 & 8.60 & 8.84 \\
\hline & 2 & 8.90 & $>3.50$ & 2.48 & 1.03 & 4.30 & 8.87 & 7.95 \\
\hline & 3 & 8.91 & $>3.50$ & 1.08 & 5.41 & 5.90 & 8.90 & 8.86 \\
\hline & 4 & 8.99 & $>3.50$ & 3.60 & 5.87 & 6.02 & 9.00 & 8.98 \\
\hline & 5 & 8.84 & $>3.50$ & 2.77 & 5.98 & 6.30 & 8.95 & 8.85 \\
\hline & 6 & 8.95 & $>3.50$ & 4.26 & 0.94 & 6.18 & 9.10 & 9.10 \\
\hline & 7 & 8.93 & $>3.50$ & 2.55 & 0.84 & 3.95 & 8.87 & 8.87 \\
\hline & 8 & 8.84 & $>3.50$ & 5.12 & 4.00 & 4.98 & 8.74 & 8.30 \\
\hline & 9 & 9.47 & $>3.50$ & 1.60 & 3.89 & 5.12 & 8.65 & 8.80 \\
\hline & 10 & 8.50 & $>3.50$ & 2.47 & 3.11 & 4.95 & 8.90 & 8.72 \\
\hline \multirow{10}{*}{$\begin{array}{l}\text { Non-licensed } \\
\text { Serrano cheese }\end{array}$} & 11 & 8.94 & $>3.50$ & 4.33 & 4.77 & 4.90 & 8.95 & 8.60 \\
\hline & 12 & 8.45 & $>3.50$ & 2.90 & 1.23 & 5.15 & 7.98 & 7.48 \\
\hline & 13 & 7.91 & $>3.50$ & 5.24 & 1.45 & 4.98 & 8.30 & 8.25 \\
\hline & 14 & 8.60 & $>3.50$ & 2.34 & 5.87 & 5.81 & 8.90 & 8.15 \\
\hline & 15 & 8.86 & $>3.50$ & 4.32 & 4.61 & 4.95 & 8.72 & 8.20 \\
\hline & 16 & 8.99 & $>3.50$ & 3.85 & 6.15 & 4.93 & 8.97 & 8.95 \\
\hline & 17 & 8.98 & $>3.50$ & 5.26 & 4.65 & 3.60 & 8.93 & 8.74 \\
\hline & 18 & 8.82 & $>3.50$ & 4.82 & 0.87 & 5.15 & 8.87 & 8.65 \\
\hline & 19 & 9.04 & $>3.50$ & 3.09 & 6.08 & 5.13 & 9.00 & 8.95 \\
\hline & 20 & 8.30 & $>3.50$ & 3.67 & 0.79 & 5.01 & 8.90 & 8.65 \\
\hline
\end{tabular}

${ }^{*}$ Most Probable Number per gram (MPN/g). 
All samples exhibited the presence of total coliforms, a fact that is common in cheeses produced from raw milk. Fecal coliforms, as determined by the evaluation of thermotolerant coliforms varied between 1.08 to 5.26 log $\mathrm{CFU} / \mathrm{g}$, and Salmonella spp. was detected in two samples $(10 \%)$, one licensed and one unlicensed cheese.

As occurred with fecal coliforms, twelve samples (60\%) were above the Brazilian limits for coagulase positive staphylococci (>3 log CFU/g) in cheese, and moulds and yeasts counting varied between 3.95 and $6.30 \log \mathrm{CFU} / \mathrm{g}$ (Table 1), with a mean value of $5.11 \mathrm{log}$ $\mathrm{CFU} / \mathrm{g}$.

As expected, lactic acid bacteria (LAB) were by far the major microbial group in Serrano cheese (7.48 to $9.10 \log \mathrm{CFU} / \mathrm{g})$. Microscopic and physiologic characterization of 278 isolates showed that $91 \%$ of LAB from commercial Serrano cheeses were lactobacilli, followed by lactococci (7\%) and enterococci (2\%).

Phenotypic characterization of lactobacilli resulted in identification of $57.7 \%$ isolates as Lactobacillus plantarum, $19.2 \%$ as $L$. paracasei, $7.7 \%$ as $L$. rhamnosus, $7.7 \%$ as $L$. acidophilus, and $3.8 \%$ of $L$. curvatus and $L$. fermentum (Figure 1). The phenotypic identification was confirmed by $16 \mathrm{~S}$ rRNA sequencing, except for one isolate of L. acidophilus.

The analysis of 33 Lactobacillus by TAP-PCR allowed identifying a total of 16 amplifications products with molecular weight between $283 \mathrm{pb}$ and $1789 \mathrm{pb}$, and a mean of 7.5 bands per strain. Most of the amplification products were polymorphic (62.5\%), corroborating the high discriminatory power of TAP-PCR [10,12].

Multivariate analysis of TAP-PCR profiles allowed separating the Lactobacillus isolates in three clusters (Figure 2). Based on phenotypic traits and sequencing data, cluster I and III were formed by L. plantarum and cluster II by $L$. paracasei isolates. Nine of the twelve cheeses examined showed 1 to 3 L. plantarum genotypes, and three cheeses exhibited the presence of both $L$. plantarum and L. paracasei.

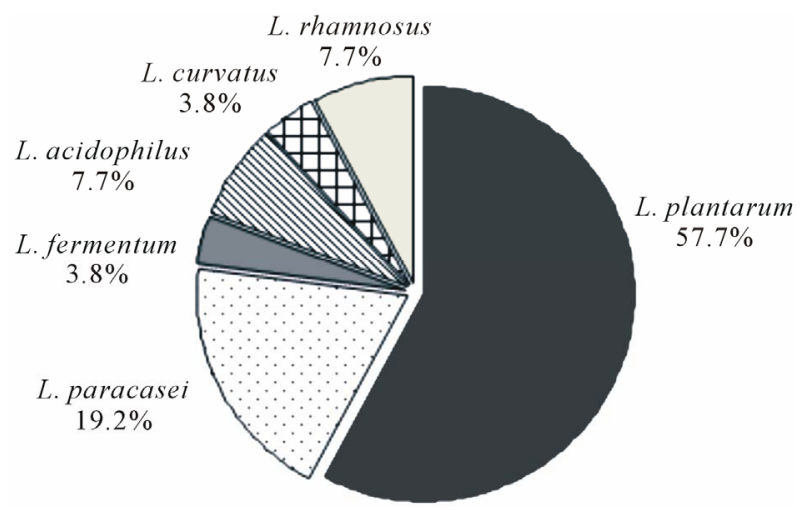

Figure 1. Prevalence of Lactobacillus species in mature Serrano cheeses.

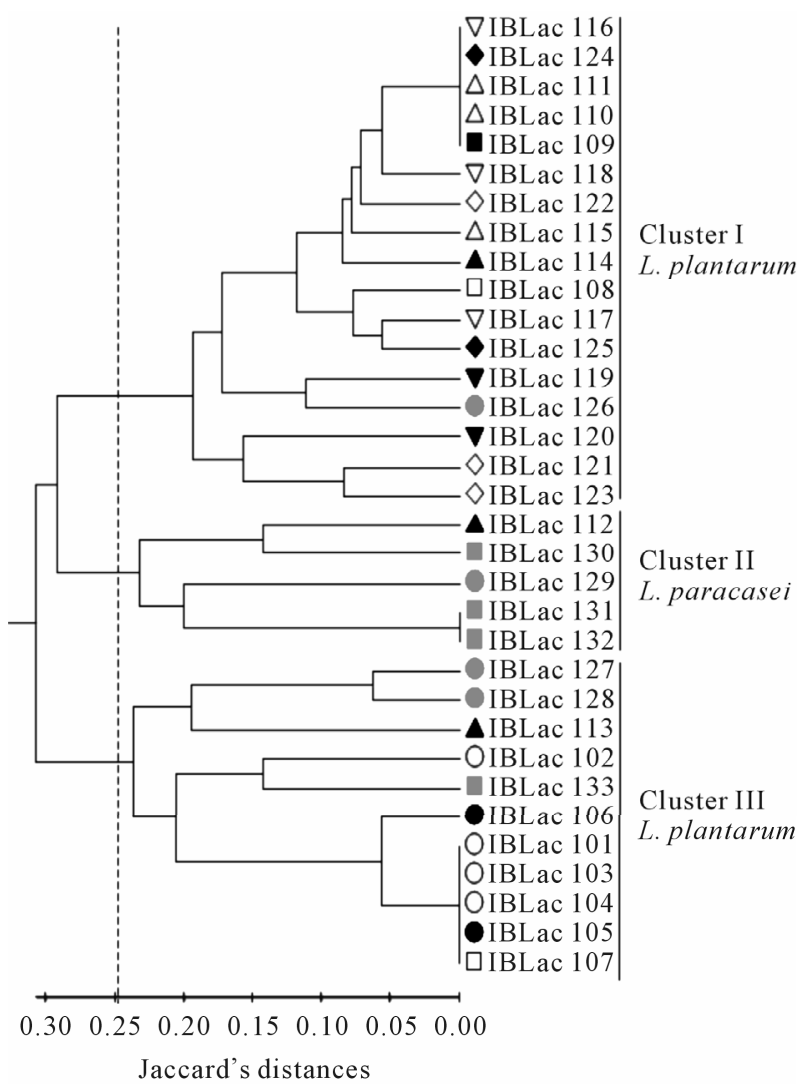

Figure 2. Dendrogram obtained from TAP-PCR analysis of Lactobacillus isolated from twelve Serrano cheeses: $1(O), 2$ ( $\square), 3(\odot), 4(\square), 5(\triangle), 6(\odot), 11(\nabla), 12(\nabla), 13(\diamond), 14$ $(\bullet), 15(\Delta)$ and $16(\square)$.

\subsection{Physico-Chemical and Sensorial Properties}

The overall results obtained by the analysis of twenty cheese samples showed that commercialized Serrano cheese is characterized by: $20.12 \% \pm 3.93 \%$ proteins, $23.66 \% \pm 3.28 \%$ fats, $3.45 \% \pm 0.57 \%$ ash, $48.93 \% \pm$ $3.06 \%$ moisture, $1.11 \% \pm 0.48 \% \mathrm{NaCl}$, and $0.48 \% \pm$ $0.21 \%$ acidity (Table 2). Non-significant differences in physicochemical parameters were detected between licensed and nonlicensed Serrano cheeses, indicating that the modifications demanded for licensing did not affect the overall characteristics of the artisanal products.

The average salt content in the samples examined varied between $0.28 \%$ and $2.06 \%$, and titratable acidity ranged from $0.23 \%$ to $0.89 \%$, with an average of $0.48 \%$.

The results of hedonic rating test (Figure 3(a)) showed that only seven out of twenty samples $(3,5,6,8,11,16$ and 19 ) received acceptability index higher than 0.7 , and were thus considered as high quality cheeses. However, a correlation analysis showed that, among those evaluated, there were no physico-chemical parameters that justify this preference. Figure 3(b) shows the profile test of the best and the worst cheeses based on the acceptability index. As can be observed, those considered as good 
Table 2. Physico-chemical parameters of commercial Serrano cheese.

\begin{tabular}{|c|c|c|c|c|c|c|c|}
\hline & Samples & Protein (\%) & Fat (\%) & Moisture (\%) & Ashes (\%) & $\mathrm{NaCl}(\%)$ & Acidity (\%) \\
\hline \multirow{11}{*}{$\begin{array}{c}\text { Licensed } \\
\text { Serrano cheese }\end{array}$} & 1 & 9.95 & 19.41 & 50.18 & 4.30 & 1.68 & 0.39 \\
\hline & 2 & 21.43 & 23.63 & 50.81 & 2.77 & 0.67 & 0.32 \\
\hline & 3 & 21.43 & 20.20 & 50.83 & 3.85 & 1.37 & 0.23 \\
\hline & 4 & 18.23 & 23.24 & 52.65 & 2.63 & 0.52 & 0.46 \\
\hline & 5 & 20.87 & 24.53 & 49.75 & 3.38 & 1.45 & 0.38 \\
\hline & 6 & 17.28 & 26.37 & 49.28 & 3.08 & 0.93 & 0.54 \\
\hline & 7 & 24.24 & 20.07 & 50.23 & 4.52 & 2.06 & 0.44 \\
\hline & 8 & 23.02 & 22.78 & 48.05 & 3.55 & 1.15 & 0.23 \\
\hline & 9 & 14.58 & 24.62 & 51.56 & 3.50 & 1.62 & 0.55 \\
\hline & 10 & 21.33 & 26.81 & 45.39 & 2.69 & 0.37 & 0.83 \\
\hline & Average & $19.34 \pm 4.33$ & $23.17 \pm 2.59$ & $49.87 \pm 2.01$ & $3.44 \pm 0.66$ & $1.18 \pm 0.55$ & $0.44 \pm 0.18$ \\
\hline \multirow{11}{*}{$\begin{array}{l}\text { Non licensed } \\
\text { Serrano cheese }\end{array}$} & 11 & 13.11 & 27.55 & 47.53 & 2.70 & 0.48 & 0.89 \\
\hline & 12 & 17.14 & 22.06 & 48.85 & 3.59 & 0.90 & 0.32 \\
\hline & 13 & 23.73 & 27.26 & 44.22 & 4.04 & 1.43 & 0.44 \\
\hline & 14 & 22.42 & 21.01 & 50.40 & 3.37 & 0.90 & 0.33 \\
\hline & 15 & 20.76 & 27.08 & 47.21 & 3.55 & 1.37 & 0.42 \\
\hline & 16 & 22.59 & 18.00 & 53.78 & 3.64 & 1.35 & 0.39 \\
\hline & 17 & 20.46 & 23.01 & 52.81 & 2.53 & 0.28 & 0.89 \\
\hline & 18 & 21.72 & 31.10 & 41.59 & 3.45 & 0.95 & 0.45 \\
\hline & 19 & 24.05 & 21.59 & 45.84 & 3.96 & 1.20 & 0.31 \\
\hline & 20 & 24.12 & 22.94 & 47.69 & 3.98 & 1.48 & 0.79 \\
\hline & Average & $21.01 \pm 3.48$ & $24.16 \pm 3.94$ & $47.99 \pm 3.71$ & $3.48 \pm 0.51$ & $1.03 \pm 0.41$ & $0.52 \pm 0.24$ \\
\hline
\end{tabular}

${ }^{1}$ Expressed as \% of lactic acid.

Serrano cheeses received the highest scores for general aspect, color, texture and flavor, but smell differences were not significant.

\section{Discussion}

\subsection{Microbiological Analysis}

The number of mesophilic bacteria in Serrano cheeses was within those previously reported by Souza et al. [2], Roos et al. [12], and Dalla Rosa et al. [13]. According to Ortolani et al. [14], values from 4 to 9 log CFU/g are normal in cheeses produced from raw milk. However, high counting of mesophilic bacteria can be an indicative of unsatisfactory sanitary conditions of raw material, processing or storage [15].

As expected in cheeses produced from raw milk, all the samples exhibited the presence of total coliforms. Even within the range reported by Kottwiz and Guimarães [16] in a study of artisanal cheeses (Paraná, Brazil), just $45 \%$ of Serrano cheese samples were in accordance with the actual Brazilian legislation [3]. These samples included $70 \%$ of licensed and $20 \%$ of unlicensed cheeses, indicating that the hygienic procedures adopted during milking and processing of licensed cheeses efficiently reduced microbial contamination. However, as reinforced by the presence of Salmonella (10\% of the samples), additional measures and police are needed to guarantee the microbiological quality and safety of Serrano cheese. Raw milk and derived products have been implicated in outbreaks of salmonellosis in several countries [17-19].

The high number of staphylococci detected in Serrano cheese can reflect inadequate raw material obtained from animals with mastitis, and/or inappropriate hygiene conditions during processing [20]. In this sense, two samples (3 and 9) exhibited low coliform and high staphylococci counts, a situation expected in milk from animals with mastitis [21]. This finding indicates that a strict police of animal health, associated with hygiene measures during milking and processing, is essential in order to obtain high quality Serrano cheeses.

The moulds and yeasts counting were within the range 


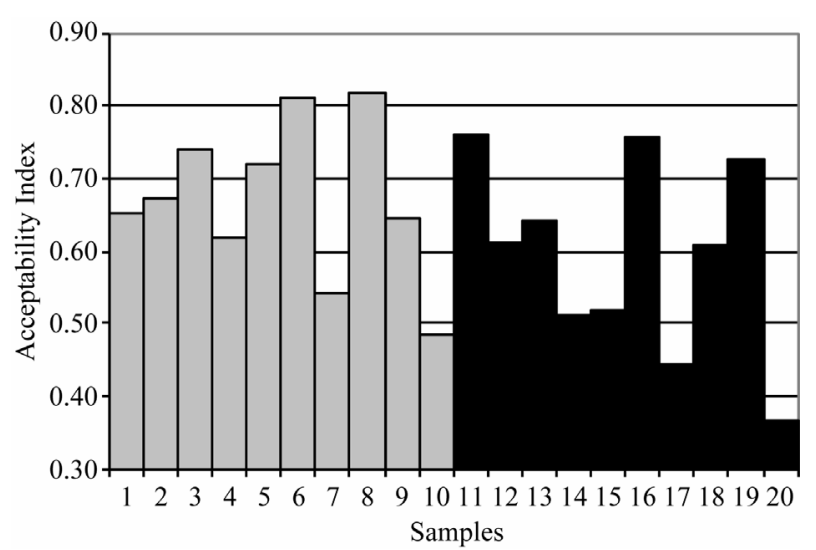

(a)

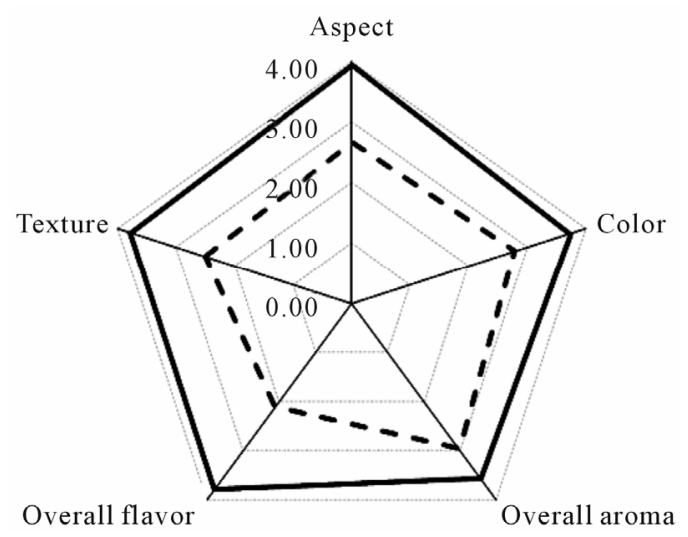

(b)

Figure 3. Acceptability index of licensed $(1-10)$ and nonlicensed (11 - 20) Serrano cheeses (a), and the average characteristic profile of the best (continouos line) and worst (dotted line) cheeses (b).

(4 - 7 log CFU/g) observed Souza et al. [2] and Landell et al. [22]. According with Fleet [23], yeast counting higher than 6 - 7 log CFU/g may represent a deterioration problem. Conversely, yeasts may be important during ripening, contributing to the flavor of final product [24].

The presence of fecal coliforms, Salmonella and staphylococci, potential foodborne gastroentheric bacteria, in both licensed and unlicensed Serrano cheeses, point out the necessity to develop an alternative manufacturing process and GMPs, in order to minimize consumers' health risks.

The mean number of lactic acid bacteria (8.8 log CFU/g) was similar to that obtained in other studies of Serrano cheese by Souza et al. [2] and Dalla Rosa et al. [13]. According to these authors, the number of lactic acid bacteria rapidly increase during the first 15 days suffering a subsequent reduction, and stabilizing in approximately $8 \log \mathrm{CFU} / \mathrm{g}$.

As Serrano cheese is manufactured with raw milk and no commercial starters are used, LAB depends entirely on natural populations (non-starter lactic acid bacteria-
NSALB). The evaluation of LAB isolates from Serrano cheese samples showed a large prevalence of lactobacilli, with lactococci and enterococci representing less than $10 \%$ of LAB. These data corroborate the results obtained by Souza et al. [2] and Dalla Rosa et al. [13].

Phenotypic and molecular classification of lactobacilli isolates showed high frequency of $L$. plantarum and $L$. paracasei in Serrano cheeses. These species have been currently found in cheeses. For example, L. plantarum was the most prevalent lactobacilli in Italian Ewe cheeses [7], where $L$. paracasei represent $64 \%$ to $96 \%$ of NSLAB isolated form Cheddar cheese $[8,10]$. A comparison between industrial and artisanal Manchego cheeses showed only Lactococcus lactis in the industrial cheeses, while in the artisanal cheeses the microflora was much more heterogeneous, including $L$. lactis, $L$. paracasei, L. plantarum, Leuconostoc, and Enterococcus [25]. Even in inoculated cheeses, non-starter lactobacilli are essential in cheese process affecting both flavor and texture attributes by increasing the level of free amino acids, peptides, and free fatty acids [10,25-30]. TAP-PCR analysis of LAB colonies isolated from 12 Serrano cheeses (Figure 2) showed that two to three genotypes of $L$. plantarum, or $L$. plantarum and L. paracasei, coexist in Serrano cheeses. The presence of more or less complex Lactobacillus communities are frequent in mature cheeses, as evidenced in Italian ewe [7], Cheddar [8,10], Manchego [29], Gouda [31] and others cheeses.

\subsection{Physico-Chemical and Sensorial Properties}

The average moisture of commercial Serrano cheeses (48.93\%) was higher than that obtained by Souza et al. [2] and Dalla Rosa et al. [13] analyzing mature samples (>40\%), and comparable to that of cheeses with only 7 days of ripening ( $45.00 \%)$. As observed by Ide and Benedet [4], commercial Serrano cheese moisture content varied between $35 \%$ and $60 \%$ with an average of $43.72 \%$. The high moisture of observed in the twenty samples allowed to classified them as soft cheeses (moisture between $46.00 \%$ and $54.90 \%$ ) in agreement with the Technical regulation of quality and cheese identity [3], and indicates that the products are commercialized after a short period of ripening, incompatible with the actual Brazilian legislation. According to Fox et al. [32] cheese moisture affects product texture, eyes formation, and flavor, becoming hard to control it in artisanal production.

The variation of salt may reflect differences in the salting process, particularly surface salting with unweighted amounts of $\mathrm{NaCl}$. Low salt concentrations in Serrano cheeses were previously detected by Ide and Benedet [4], Souza et al. [2], and Dalla Rosa et al. [13]. Most analyzed cheeses (95\%) showed less than $2 \% \mathrm{NaCl}$, a concentration that is not enough to inhibit enterobacterial 
growth, explaining the high mesophilic and coliform counts. Moreover, higher salt concentration can contribute to reduce moisture by favoring free water expulsion from the curd.

The titratable acidity values are lowers than those reported by Ide and Benedet [4] and Souza et al. [2]. Low acidity reflects a short ripening period or inadequate lactic acid fermentation during ripening. The use of starter cultures or selected NSLAB from a previous fermentation can overcome this problem and contribute for a reduction in non-desirable bacterial populations.

The protein and fat contents were similar than those previously reported by Ide and Benedet [4]. The huge variation observed in both parameters can be explained by moisture differences, and variation in herd performance regardless milk production [33]. The low fat content of Serrano cheeses, when compared with other similar products, can be attributed to the use of milk from low refined genetic animals, pasture quality, and non-feeding supplementation.

Hedonic rating test showed that only $60 \%$ of the cheeses evaluated were considered as typical Serrano cheeses. Although no significant, the average acceptability of licensed cheeses was slightly higher than that of non-licensed samples, indicating that good production practices positively affect cheese quality maintaining its typical character. Cheeses that received the highest scores exhibited the presence of both $L$. plantarum and $L$. paracasei, indicating that mixed populations of these species positively contributed to flavor development. Base in these results, the inoculation of curd with selected cultures of $L$. plantarum and $L$. paracasei may be seen as an option to increase the quality of Serrano cheese.

\section{Conclusions}

Serrano cheeses, traditionally produced with raw milk in the highlands of South Brazil, showed high prevalence of mesophilic bacteria, fecal coliforms and staphylococci. Although GMP, adopted to obtain cheese licensing, led to a reduction of the number of undesirable microorganisms, more restrict monitoring of animal health, alternative manufacturing processes, and other GMP measures are essential to attain high microbiological quality of the final product reducing the potential risk to the consumers.

Considering the number of NSLAB, Serrano cheeses are the product of Lactobacillus fermentation, particularly L. plantarum and L. paracasei. Cheeses with both species received the highest sensorial scores, indicating that the inoculation with selected strains of these species can be adopted to increase the sensorial quality. Moreover, as occurs in other cheeses, the inoculation with selected LAB strains will rapidly reduce the $\mathrm{pH}$ and nu- trients availability for undesirable microorganisms, helping to reduce their population.

\section{Acknowledgements}

The authors wish to thank SCT-RS and FAPERGS for their financial support, and CNPq for the scholarship to C.C.P.A. and F.M.

\section{REFERENCES}

[1] USDA-FAS, "Cheese Consumption Summary for Selected Countries,” 2012. http://www.fas.usda.gov/htp/2011_July_dairy.pdf

[2] C. F. V. Souza, T. Dalla Rosa and M. A. Z. Ayub, "Changes in the Microbiological and Physicochemical Characteristics of Serrano Cheese during Manufacture and Ripening,” Brazilian Journal Microbiology, Vol. 34, No. 3, 2003, pp. 260-266. doi:10.1590/S1517-83822003000300016

[3] MAPA, “Portaria No. 146/96,” Diário Oficial, Brasília, 1996.

[4] L. P. A. Ide and H. D. Benedet, "Contribuição ao Conhecimento do Queijo Colonial Produzido na Região Serrana do Estado de Santa Catarina, Brasil," Ciência Agrotécnica, Vol. 25, 2001, pp. 1351-1358.

[5] International Dairy Federation, "Milk and Milk Products-Methods of Sampling,” IDF, Brussels, 1985.

[6] MAPA, "Instrução Normativa No. 62-Métodos Analíticos Oficiais para Análises Microbiológicas para Controle de Produtos de Origem Animal e Água,” Diário Oficial, Brasília, 2003.

[7] M. De Angelis, A. Corsetti, N. Tosti, J. Rossi, M. R. Corbo and M. Gobbetti, "Characterization of Non-Starter Lactic Acid Bacteria form Italian Ewe Cheeses Based on Phenotypic, Genotypic, and Cell Wall Protein Analyses,” Applied Environmental Microbiology, Vol. 67, 2001, pp. 2011-2020. doi:10.1128/AEM.67.5.2011-2020.2001

[8] N. A. Fitzsimons, T. M. Cogan, S. Condon and T. Beresford, "Phenotypic and Genotypic Characterization of Non-Starter Lactic Acid Bacteria in Mature Cheddar Cheese," Applied Environmental Microbiology, Vol. 65, No. 8, 1999, pp. 3418-3426.

[9] J. L. Jany and G. Barbier, "Culture-Independent Methods for Identifying Microbial Communities in Cheese,” Food Microbiology, Vol. 25, No. 7, 2008, pp. 839-848. doi:10.1016/j.fm.2008.06.003

[10] P. A. Swearingen, D. J. O’Sullivan and J. J. Warthesen, "Isolation, Characterization, and Influence of Native NonStarter Lactic Acid Bacteria on Cheddar Cheese Quality," Journal Dairy Science, Vol. 84, 2001, pp. 50-59. doi:10.3168/jds.S0022-0302(01)74451-7

[11] AOAC, “Official Methods of Analysis," Association of Official Agricultural Chemists, Washington, 2003.

[12] T. B. Roos, V. B. S. Filho, C. D. Timm and D. S. Oliveira “Avaliação Microbiológica de Queijo Colonial Produzido na Cidade de Três Passos, RS,” Higiene Alimentar, Vol. 
19, 2005, pp. 94-96.

[13] T. Dalla Rosa, G. E. Wassermann, C. F. V. de Souza, D. Caron, C. R. Carlini and M. A. Z. Ayub, "Microbiological and Physicochemical Characteristics and Aminopeptidase Activities during Ripening of Serrano Cheese," International Journal Dairy Technology, Vol. 61, No. 1, 2008, pp. 70-79.

[14] M. B. T. Ortolani, A. K. Yamazi, P. M. Moraes, G. N. Viçosa and L. A. Nero, "Microbiological Quality and Safety of Raw Milk and Soft Cheese and Detection of Autochthonous Lactic Acid Bacteria with Antagonistic Activity against Activity against Listeria monocytogenes, Salmonella spp., and Staphylococcus aureus," Food Pathogens and Disease, Vol. 7, No. 2, 2010, pp. 175-180. doi:10.1089/fpd.2009.0390

[15] M. L. Tortorello, "Indicator Organisms for Safety and Quality-Uses and Methods for Detection: Minireview," Journal of AOAC International, Vol. 88, No. 6, 2003, pp. 1208-1217.

[16] L. B. M. Kottwitz and I. M. Guimarães, “Avaliação Microbiológica de Queijos Coloniais Produzidos no Estado do Paraná,” Higiene Alimentar, Vol. 17, No. 114-115, 2003, pp. 77-80.

[17] M. Kousta, M. Mataragas, P. Skandamis and E. H. Drosinos, "Prevalence and Sources of Cheese Contamination with Pathogens at Farm and Processing Levels," Food Control, Vol. 21, 2010, pp. 805-815. doi:10.1016/i.foodcont.2009.11.015

[18] S. O. Yagoub, N. A. M. Oshi and E. M. Z. Ibtisam, "Isolation and Susceptibility to Antimicrobial Agents of Salmonella paratyphi from Cheese in Khartoum (Sudan)," Research Journal of Microbiology, Vol. 5, No. 5, 2010, pp. 740-744.

[19] J. Mazurek, E. Salehi, D. Propes, J. Holt, T. Bannerman, I. M. Nicholson, M. Bundensen, R. Duffy and R. I. Moolenaar, "A Multistate Outbreak of Salmonella enterica Serotype Typhimurium Infection Linked to Raw Milk Consumption-Ohio, 2003,” Journal Food Protection, Vol. 67, No. 10, 2004, pp. 2165-2170.

[20] E. Vautor, G. Abadi, J. M. Guibert, C. Huard and M. Pépin, "Genotyping of Staphylococcus Aureus Isolated from Various Sites on Farms with Dairy Sheep Using Pulsed-Field Gel Electrophoresis," Veterinary Microbiology, Vol. 96, No. 1, 2003, pp. 69-79. doi:10.1016/S0378-1135(03)00207-4

[21] S. P. Oliver, B. M. Jayarao and R. A. Almeida, "Foodborne Pathogens, Mastitis, Milk Quality, and Dairy Food Safety," 43rd National Mastitis Council-Annual Meeting Proceedings, Orlando, 2005, pp. 3-27.

[22] M. F. Landell, C. Hartfelder and P. Valente, "Identification and Enzymatic Profile of Yeasts Isolated from Ar- tisanal Cheese in Southern Brazil," Acta Scientiae Veterinariae, Vol. 34, No. 1, 2006, pp. 49-55.

[23] G. H. Fleet, "Yeasts in Dairy Products-A Review," Journal Applied Bacteriology, Vol. 68, No. 3, 1990, pp. 199-211.

[24] K. Lavoie, M. Touchette. D. Sr-Gelais and S. Labrie "Characterization of the Fungal Microflora in Raw Milk and Specialty Cheeses of the Province of Quebec,” Dairy Science \& Technology, 2011.

[25] C. Ballesteros, J. M. Poveda, M. A. González-Viñas and L. Cabezas, "Microbiological, Biochemical and Sensory Characteristics of Artisanal and Industrial Manchego Cheeses," Food Control, Vol. 17, No. 4, 2006, pp. 249255. doi:10.1016/j.foodcont.2004.10.008

[26] P. L. H. McSweeney, P. F. Fox, J. A. Lucey, K. N. Jordan and T. M. Cogan, "Contribution of the Indigenous Microflora to the Maturation of Cheddar Cheese,” International Dairy Journal, Vol. 3, No. 7, 1993, pp. 613-634. doi:10.1016/0958-6946(93)90104-8

[27] C. N. Lane and P. F. Fox, "Contribution of Starter and Added Lactobacilli to Proteolysis in Cheddar Cheese during Ripening,” International Dairy Journal, Vol. 6, No. 7, 1996, pp. 715-728. doi:10.1016/0958-6946(95)00067-4

[28] A. Corsetti, M. Gobbetti, E. Smacchi, M. De Angelis and J. Rossi, "Accelerated Ripening of Pecorino Umbro Cheese,” Journal of Dairy Science, Vol. 65, 1998, pp. 631-642.

[29] L. Cabezas, I. Sánchez, J. M. Poveda, S. Seseña and M. L. L. Palop, "Composition of Microflora, Chemical and Sensory Characteristics of Artisanal Manchego Cheeses from Two Dairies," Food Control, Vol. 18, 2007, pp. 11-17. doi:10.1016/j.foodcont.2005.07.010

[30] P. Nieto-Arribas, J. M. Poveda, S. Seseña, M. L. L. Palop and L. Cabezas, "Technological Characterization of Lactobacillus isolates from Traditional Manchego Cheese for Potential Use as Adjunct Starter Cultures," Food Control, Vol. 20, 2009, pp. 1092-1098. doi:10.1016/j.foodcont.2009.03.001

[31] K. Van Hoorde, T. Verstraete, P. Vandamme and G. Huys, "Diversity of Lactic Acid Bacteria in Two Flemish Artisan Raw Milk Gouda-Type Cheeses,” Food Microbiology, Vol. 25, No.7, 2008, pp. 929-935. doi:10.1016/j.fm.2008.06.006

[32] P. F. Fox, P. L. H. McSweeney, T. M. Cogan and T. P. Guinee, "Cheese: Chemistry, Physics and Microbiology," 3rd Edition, Vol. 1. Elsevier Ltd., London, 2004.

[33] N. Y. Farkye, “Cheese Technology,” International Journal Dairy Technology, Vol. 57, No. 2-3, 2004, pp. 91-98. doi:10.1111/j.1471-0307.2004.00146.x 